\title{
List of Maps, Tables, and Illustrations
}

Maps

1. Central-Western Brazil and Indigenous Populations 24

2. Itinerary of Roncador-Xingu Expedition 47

3. Xavante Migrations 61

4. Mato Grosso State and Barra do Garças County, 195892

5. Amazonia 139

6. Culuene and Couto Magalhães Reserves, 1976166

7. Parabubure Reserve, $1980 \quad 182$

8. Xavante Reserves, 1986191

Tables

1. SUDAM Fiscal Incentives, 1965-1973 149

2. Cadastral Statistics for Barra do Garças County, 1972151

3. Xavante Reserves by Area and Population, $1990 \quad 189$

Illustrations

1. Aerial photograph of Xavante Village 109

2. Getúlio Vargas and Cândido Rondon, $1940 \quad 109$

3. Xavante warriors 110

4. Contact between Xavante and SPI attraction team 110

5. Francisco Meireles and a Xavante Indian 111

6. Getúlio Vargas and Xavante Indians at Catete Palace, 1954111

7. Xavante Indian with knife at Pimentel Barbosa Post 112

8. Urubuenã and Walter Velloso at Capitariquara Post 112

9. Celestino descends on FUNA I headquarters in Brasília, 1980 113 
